\title{
Mites are the most common vectors of the fungus Gondwanamyces proteae in Protea infructescences
}

\author{
Francois ROETS $^{a, *}$, Michael J. WINGFIELD ${ }^{b}$, Brenda D. WINGFIELD ${ }^{b}$, Leanne L. DREYER ${ }^{c}$ \\ ${ }^{a}$ Department of Conservation Ecology and Entomology, Stellenbosch University, Stellenbosch, South Africa \\ ${ }^{b}$ Forestry and Agricultural Biotechnology Institute (FABI), University of Pretoria, Pretoria, South Africa \\ ${ }^{c}$ Department of Botany and Zoology, Stellenbosch University, Stellenbosch, South Africa
}

\section{A R T I C L E I N F O}

\section{Article history:}

Received 5 July 2010

Received in revised form

1 December 2010

Accepted 20 January 2011

Corresponding Editor: Judith K. Pell

Keywords:

Custingophora

Fungal transmission

Mites

Sporothecae

Tarsonemus

\begin{abstract}
A B S T R A C T
Entomochoric spore dispersal is well-documented for most ophiostomatoid fungal genera, most of which are associated with bark or ambrosia beetles. Gondwanamyces spp. are unusual members of this group that were first discovered in the flower heads of the primitive angiosperm genus Protea, that is mostly restricted to the Cape Floristic region of Africa. In this study, we present the discovery of the vectors of Gondwanamyces proteae in Protea repens infructescences, which were identified using PCR, direct isolation, and light microscopy. Gondwanamyces proteae DNA and ascospores were identified on diverse lineages of arthropods including beetles (Euderes lineicolis and Genuchus hottentottus), bugs (Oxycarenus maculates), a psocopteran species and five mite (Acari) species. Based on isolation frequency, however, a mite species in the genus Trichouropoda appears to be the most common vector of G. proteae. Gondwanamyces spores were frequently observed within pit mycangia at the base of the legs of these mites. Manipulative experiments demonstrated the ability of mites to carry viable $G$. proteae spores whilst in transit on the beetle G. hottentottus and that these mites are able to transfer G. proteae spores to uncolonised substrates in vitro. Interestingly, this same mite species has also been implicated as vector of Ophiostoma spores on $P$. repens and belongs to the same genus of mites that vector Ophiostoma spp. associated with pine-infesting bark beetles in the Northern Hemisphere.
\end{abstract}

๑ 2011 The British Mycological Society. Published by Elsevier Ltd. All rights reserved.

\section{Introduction}

The ophiostomatoid fungi (Wingfield et al. 1993) include species that reside in two distantly related orders, the Ophiostomatales and the Microascales (Hausner et al. 1992; 1993a; 1993b; Spatafora \& Blackwell 1994). Species in these orders have undergone convergent evolution that promotes entomochoric spore dispersal and are often treated collectively due to their morphological and ecological similarities, despite a lack of phylogenetic relatedness (Spatafora \& Blackwell 1994). Ophiostomatoid fungi generally produce flask-shaped sexual structures with extended necks (teleomorph) or stalklike asexual structures (anamorph) that bear sticky spore droplets at their tips. These exposed spores are ideally positioned to easily adhere to, and be dispersed by, arthropods (Münch 1907; 1908; Francke-Grosmann 1967; Whitney 1982; Beaver 1989; Malloch \& Blackwell 1993; Cassar \& Blackwell 1996).

The ophiostomatoid fungi have a global distribution, but are best known in the Northern Hemisphere. In this region they are typically associated with the galleries of bark and ambrosia beetles (Coleoptera: Curculionidae, Scolytinae), which are particularly well-studied on conifers (Francke-Grosmann

\footnotetext{
* Corresponding author. Tel.: +27 021808 2635; fax: +27 0218083304.

E-mail address: fr@sun.ac.za
}

1878-6146/\$ - see front matter @ 2011 The British Mycological Society. Published by Elsevier Ltd. All rights reserved. doi:10.1016/j.funbio.2011.01.005 
1967; Upadhyay 1981; Whitney 1982; Christiansen et al. 1987; Wingfield et al. 1993; Paine et al. 1997; Kirisits 2004). The group includes a number of primary plant pathogens and many agents of timber degradation (Münch 1907; Upadhyay 1981; Whitney 1982; Sinclair et al. 1987; Seifert et al. 1993; Jacobs \& Wingfield 2001).

A unique and unusual assemblage of saprobic ophiostomatoid fungi occurring in the flower heads (infructescences) of the African endemic plant genus Protea was first discovered during the latter part of 20th century (Wingfield et al. 1988). Currently, 11 species in two genera, Ophiostoma (Ophiostomatales) and Gondwanamyces (Microascales), are known only from the senescent infructescences of these plants. Ophiostoma is the more speciose genus in this niche, including seven South African species; Ophiostoma africanum, Ophiostoma gemellus, Ophiostoma protearum, Ophiostoma splendens, Ophiostoma palmiculminatum, Ophiostoma phasma, and the anamorphic Sporothrix variecibatus (Marais \& Wingfield 1994; 1997; 2001; Roets et al. 2006a; 2008). Two additional species, Ophiostoma protea-sedis and Ophiostoma zambiensis were recently added from Protea caffra in Zambia (Roets et al. 2010), confirming the distribution of Protea-associated Ophiostoma into tropical and sub-tropical Africa (Roets et al. 2009b). In addition to these, numerous other South African Ophiostoma spp. have been described from very diverse habitats, including soil, wooden utility poles used to support overhead power lines (de Meyer et al. 2008), and wounds on native trees (Kamgan et al. 2008).

In contrast to Ophiostoma, only two species of the teleomorph genus Gondwanamyces have been described from Africa (Gondwanamyces proteae and Gondwanamyces capensis). These species are known only from the infructescences of Protea species in the Western Cape Province of South Africa. Gondwanamyces proteae appears to be specific to its Protea repens host, while G. capensis has been collected from many different Protea spp. (Roets et al. 2009b). A third species, Gondwanamyces scolytodes, is associated with the ambrosia beetle Scolytodes unipunctatus (Coleoptera: Curculionidae, Scolytinae) on the plant host Cecropia angustifolia in mountain cloud rainforests of Costa Rica (Kolarik \& Hulcr 2009).

Gondwanamyces spp. are characterised by Custingophora anamorphs, cycloheximide sensitivity and a phylogenetic position inferred from rDNA sequences (Marais et al. 1998; Viljoen et al. 1999; Kolarik \& Hulcr 2009). Two Custingophora spp. are thought to be closely related to Gondwanamyces (Kolarik \& Hulcr 2009); Custingophora olivacea which was described from compost in Germany (Stolk \& Hennebert 1968), and Custingophora cecropiae is known as associate of S. unipunctatus on C. angustifolia (Kolarik \& Hulcr 2009). The phylogenetic relatedness of these two species to the other four species in Custingophora is unknown (Pinnoi et al. 2003; Kolarik \& Hulcr 2009).

Like other ophiostomatoid fungi, those associated with Protea were presumed to be entomochoric. This was based on general morphology with ascospores and conidia produced in sticky drops on the tips of elongated structures (Wingfield et al. 1988; Wingfield \& Van Wyk 1993; Marais \& Wingfield 1994). More recent studies have confirmed the association of Protea-colonising Ophiostoma with arthropods (Roets et al. 2006c; 2007; 2008). Various mites (Proctolaelaps vandenbergi, two Tarsonemus spp. and a Trichouropoda sp.) play a primary role in the dissemination of Ophiostoma spores on Protea
(Roets et al. 2007). In addition, the Trichouropoda sp. has a mutualistic association with its phoretic Ophiostoma spp. It was thus shown that this mite is able to complete its life cycle on a diet consisting solely of Ophiostoma spp. In a subsequent study, Roets et al. (2009a) demonstrated that long-range dispersal of the mites and their associated Ophiostoma spp. is achieved through a phoretic association with the beetles Genuchus hottentottus, Trichostetha fascicularis, and Trichostetha capensis.

In contrast to Ophiostoma, nothing is known regarding the dispersal of Protea-associated Gondwanamyces spp. The closely related species C. cecropiae and G. scolytodes have been collected from Scolytodes and are presumed to be dispersed by these beetles (Kolarik \& Hulcr 2009). Other closely related fungi in the genus Ceratocystis (Microascales) are vectored by various insects (Iton 1966; Moller \& DeVay 1968; Hinds 1972; Kile 1993) including bark beetles (Yamaoka et al. 1997; Harrington \& Wingfield 1998; Krokene \& Solheim 1998). However, no bark or ambrosia beetles are known to be associated with Protea spp. Based on the morphological similarity between Gondwanamyces and Ophiostoma, it is reasonable to suspect that Gondwanamyces spp. have vectors similar to those for Ophiostoma spp. occurring on its Protea hosts.

The aim of this study was to evaluate various arthropods as potential dispersal agents for Gondwanamyces on Protea. The investigation is focussed specifically on G. proteae that occurs exclusively on $P$. repens individuals, because this fungus has ascospores with a very distinct shape that cannot easily be confused with other fungal species from this niche.

\section{Materials and methods}

\section{Arthropod collection}

Three hundred, 1-y-old Gondwanamyces proteae-colonised Protea repens infructescences were collected from the Jonkershoek Forestry Reserve, Stellenbosch in the Western Cape Province of South Africa $\left(33^{\circ} 58.591^{\prime} S 18^{\circ} 56.817^{\prime} E\right)$ between Jan. 2003 and Aug. 2008. Infructescences were placed in emergence cages (Roets et al. 2007) at room temperature and all arthropod individuals that emerged over a 40 -d-period were collected at $3 \mathrm{~d}$ intervals. This method allowed for the collection of large arthropods (up to $4 \mathrm{~mm}$ ) only. In order to collect smaller organisms such as mites, a number of additional G. proteae-colonised infructescences (ca. 100) were opened directly after collection from the field. Individuals of small species were then extracted using a fine camel-hair brush and a dissecting needle.

The surfaces of larger arthropods were cleared of debris and phoretic arthropods using a dissecting needle. All collected arthropods were classified into morpho-species and stored at $-20^{\circ} \mathrm{C}$ until further analysis. Voucher specimens are maintained in the insect collection (USEC), Department of Conservation Ecology and Entomology, Stellenbosch University, Stellenbosch, South Africa (Table 1).

\section{Vector identification using polymerase chain reaction (PCR)}

Molecular identification of putative Gondwanamyces vectors followed methods described by Roets et al. (2007). In that study, arthropods were tested for the presence of Ophiostoma DNA using 
Table 1 - Arthropods collected from the infructescences of Protea repens and tested for the presence of (1) Gondwanamyces DNA using PCR techniques and (2) Gondwanamyces reproductive propagules using plating techniques. Species in bold were found to carry Gondwanamyces DNA and/or reproductive propagules. Numbers between parentheses indicate number of individuals that tested positive using a particular technique.

\begin{tabular}{|c|c|c|c|c|}
\hline \multirow[t]{2}{*}{ Arthropod taxa } & \multirow[t]{2}{*}{ Ref. nr } & \multicolumn{3}{|c|}{ Number of individuals } \\
\hline & & Tested using PCR & Tested using plating & Total (\%) \\
\hline \multicolumn{5}{|l|}{ Insects } \\
\hline Argyroploce sp. Hübner (Tortricidae) & 68 & 7 & 1 & 0.00 \\
\hline Curculionidae sp. & 48 & 4 & 4 & 0.00 \\
\hline Diptera sp. & 5 & 12 & 8 & 0.00 \\
\hline Euderes lineicolis Wiedemann (Curculionidae) & 33 & 9 & $14(1)$ & 4.35 \\
\hline Formicidae (sp. 2) & 56 & 9 & 20 & 0.00 \\
\hline Genuchus hottentottus (F) (Scarabaeidae) & 70 & $28(3)$ & $121(6)$ & 3.60 \\
\hline Histeridae & 32 & 7 & 1 & 0.00 \\
\hline Nitidulidae & 25 & 30 & 19 & 0.00 \\
\hline Oxycarenus maculates Stal. (Lygaeidae) & 7 & 51 & $100(1)$ & 0.01 \\
\hline Psocoptera (sp. 1) & 31 & 12 & 100 & 0.00 \\
\hline Psocoptera (sp. 2) & 12 & 4 & $100(1)$ & 0.01 \\
\hline Psocoptera (sp. 3) & 13 & 66 & 100 & 0.00 \\
\hline Sphenoptera Solier sp. (Buprestidae) & 49 & 2 & 1 & 0.00 \\
\hline Staphylinidae sp. & 35 & 1 & 6 & 0.00 \\
\hline Tinea sp. L. (Tineidae) & 67 & 4 & 1 & 0.00 \\
\hline \multicolumn{5}{|l|}{ Mites } \\
\hline Ameroseius proteaea Ryke (Ameroseiidae) & M1 & 18 & $250(8)$ & 0.03 \\
\hline Trichouropoda sp. Berlese (Uropodidae) & M2 & 23 & $400(56)$ & 13.24 \\
\hline Tarsonemus sp. & M13 & 0 & $250(5)$ & 0.02 \\
\hline Lorryia sp. Oudemans (Tydeidae) & M3 & 1 & 173 & 0.00 \\
\hline Tenuelamellarea hispanica Subias \& Itor. (Lamellareidae) & M4 & 3 & 198 & 0.00 \\
\hline Humerobates setosus Behan-Pelletier \& Mahunka (Humerobatidae) & M5 & 2 & $250(1)$ & 0.00 \\
\hline Bdellodes sp. Oudemans (Bedellidae) & M6 & 1 & 111 & 0.00 \\
\hline Proctolaelaps vandenbergi Ryke (Ascidae) & M7 & 14 & $250(1)$ & 0.00 \\
\hline Zygoribatula setosa Evans (Oribatulidae) & M8 & 2 & 14 & 0.00 \\
\hline
\end{tabular}

a PCR protocol developed by Roets et al. (2006c). In this study, we evaluated all arthropods collected from Protea repens and tested them for the presence of Gondwanamyces DNA using similar methods. The same total genomic DNA extracted from macerated individuals (Roets et al. 2007) was used in the current study to test for amplification of Gondwanamyces DNA.

Expected product length after amplification of Gondwanamyces DNA with the primers GPR1 (Roets et al. 2006c) and LR6 (Vilgalys \& Hester 1990) was ca. $640 \mathrm{bp}$. To verify positive amplification results, PCR products of this length were cleaned (Wizard ${ }^{\circledR}$ SV gel and PCR clean-up system, Promega, Madison, Wisconsin, U.S.A.) and sequenced (Big Dye ${ }^{\mathrm{TM}}$ Terminator v3.0 cycle sequencing premix kit, Applied Biosystems, Foster City, CA, U.S.A) with an ABI PRISIM ${ }^{\mathrm{TM}} 3100$ Genetic Analyser (Applied Biosystems).

\section{Vector identification by direct plating of arthropods}

To verify the putative vectors for Gondwanamyces proteae, individuals collected from emergence cages and directly from infructescences were tested for the presence of Gondwanamyces reproductive propagules using techniques described by Roets et al. (2007). Individuals were crushed and, depending on the size of the arthropod, vortexed in $2-10 \mathrm{ml} d \mathrm{dH}_{2} \mathrm{O}$. Suspensions were plated on Petri dishes $(1 \mathrm{ml} /$ plate) containing $2 \%$ malt extract agar [(MEA), Biolab, Midrand, South Africa] emended with streptomycin sulphate $\left(0.04 \mathrm{~g} \mathrm{~L}^{-1}\right)$.
Plates were incubated at $25^{\circ} \mathrm{C}$ in the dark and inspected at 48 hourly intervals for fungal growth. Colonies of Gondwanamyces, recognised in culture by their Custingophora anamorphs are very slow-growing (Wingfield et al. 1988; Wingfield \& Van Wyk 1993). All colonies of non-Gondwanamyces isolates were thus cut from the agar in Petri dishes using a scalpel as soon as these appeared. Arthropod individuals were recorded as non-carriers of Gondwanamyces reproductive propagules where no colonies of this genus appeared after 4 weeks of incubation. The presence and identity of putative Gondwanamyces isolates (as Custingophora asexual states) were determined using colony- and microscopic fungal characteristics. One Gondwanamyces colony per arthropod individual was randomly chosen as a representative culture for the collection. Representative cultures were deposited in the culture collection (STE-U) of the Department of Plant Pathology, Stellenbosch University, South Africa.

\section{Vector identification by light microscopy}

Approximately 500 individuals of the suspected primary vector (a mite species in the genus Trichouropoda) were collected from Protea repens infructescences heavily colonised by Gondwanamyces proteae, from the Jonkershoek Nature Reserve. These arthropods were mounted on microscope slides in lactophenol containing cotton blue. Mounts were heated over an open flame for $10 \mathrm{~s}$ and the position of fungal spores was identified 
using a Nikon Eclipse E600 light microscope with differential interference contrast. Microscopic examinations focused on detecting ascospores that have a distinct morphology. This is in contrast to the conidia formed by Custingophora spp. that are easily confused with those of other fungal taxa. Ascospores of $G$. proteae are one celled, hyaline, fusiform with a distinct falcate hyaline gelatinous sheath, 7-13 $\times 2-4 \mu \mathrm{m}$ and they tend to stick together (Wingfield et al. 1988). Photographic images were captured using a Nikon DXM1200 digital camera.

\section{Dispersal of Gondwanamyces proteae}

Gondwanamyces proteae-colonised Protea repens infructescences $(n=100)$ that also showed insect borer damage were collected from Gordon's Bay $\left(34^{\circ} 04^{\prime \prime} 58.80^{\prime} \mathrm{S} 21^{\circ} 15^{\prime \prime} 20.52^{\prime} \mathrm{E}\right)$ during Oct. 2010 and placed in emergence cages as described by Roets et al. (2007). Boxes were left open and placed in a dark room $6 \mathrm{M}$ from an uncovered, closed window. A shallow tray $(5 \mathrm{~cm}$ deep) and sized to fit the window sill was placed in front of the window. As the infructescences dried, individuals of Genuchus hottentottus (Scarabeidae: Coleoptera; one of the main vectors of Protea infructescence-associated mites identified in Roets et al. (2009a)) that emerged, flew to the window and landed in the tray. Individuals of $G$. hottentottus were collected from the tray on a daily basis over a 3-week-period. When present, individuals of Trichouropoda sp. mites were aseptically removed with a fine dissecting needle and individually stored at $4{ }^{\circ} \mathrm{C}$ in Eppendorf tubes. Collected mites were processed within

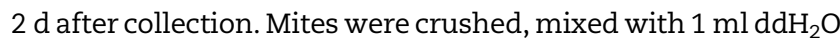
and plated onto $2 \%$ MEA plates amended with streptomycin sulphate $\left(0.04 \mathrm{gL}^{-1}\right)$. Plates were periodically inspected for the presence of Custingophora colonies over a 3-week-period.

\section{Inoculation of MEA with Gondwanamyces proteae by mites}

Gondwanamyces proteae-colonised Protea repens infructescences were collected from the Jonkershoek Forestry Reserve during Jul. 2009 and Oct. 2010. Trichouropoda sp. mites were collected from these using methods described in Roets et al. (2009a). Briefly these methods entail the collection of mites that move freely from infructescences, up plant stems and into artificially constructed 'infructescences' (darkened glass vials containing moist filter paper shreds) under desiccating conditions. Individuals of the collected mites were allowed to move freely on Petri dishes containing $2 \%$ MEA emended with $0.04 \mathrm{~g} \mathrm{~L}^{-1}$ streptomycin sulphate (one mite per dish). The experiment was replicated 250 times. In order to confirm the presence of G. proteae spores on the collected mites, an additional 131 mites were

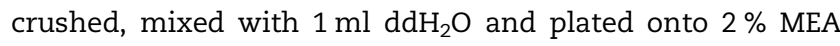
plates emended with streptomycin sulphate $\left(0.04 \mathrm{~g} \mathrm{~L}^{-1}\right)$. Petri dishes were kept at $24^{\circ} \mathrm{C}$ in the dark and regularly inspected for the presence of Custingophora colonies for 5 weeks.

\section{Results}

\section{Arthropod collection}

Various arthropod morpho-species collected by Roets et al. (2007) and in this study were excluded from further analyses as they were considered unlikely to act as primary vectors of Gondwanamyces proteae. These included all spiders and arthropod morpho-species for which less that 10 individuals were collected in total. These arthropods were considered 'tourists' on Protea repens and were thus unlikely to be specifically associated with this plant species. A total of 24 arthropod morphospecies were finally included in the analyses (Table 1).

\section{Vector identification using PCR}

Four arthropod individuals (three morpho-species) produced DNA amplicons of ca. 640 bp in length using the newly developed PCR method (Roets et al. 2006c). Sequencing of these DNA fragments, however, revealed that only Genuchus hottentottus carried Gondwanamyces DNA (Table 1). Consistent with the study of Roets et al. (2007) for the amplification of Ophiostoma DNA from arthropods, this PCR method did not exclusively amplify DNA of Gondwanamyces. It did, however, allow for the rapid screening of a large number of individuals for putative Gondwanamyces vectors.

\section{Vector identification by direct plating of arthropods}

Only $3 \%$ of tested arthropod individuals $(n=2679)$ yielded cultures of Gondwanamyces proteae using plating techniques (Table 1). These putative vector morpho-species were taxonomically very diverse and included beetles (e.g. Euderes lineicolis and Genuchus hottentottus), a bug (e.g. Oxycarenus maculates), a psocopteran species and five mite species. The frequency of morpho-species individuals found carrying spores of G. proteae was, however, generally very low (0.01-0.03\%). Individuals of the two beetles, E. lineicolis and G. hottentottus, carried reproductive propagules of G. proteae at intermediate frequencies $(4.35 \%$ and $3.60 \%$, respectively).

In contrast to other morpho-species tested, many individuals of the Trichouropoda sp. mite carried G. proteae reproductive propagules. Gondwanamyces proteae isolates were obtained from more than $13 \%$ of all individuals $(n=456)$ of this mite species (Table 1). Trichouropoda sp. mites were found to be common in the larval tunnels of boring insects, e.g. G. hottentottus in Protea repens infructescences as previously reported by Roets et al. 2007. These mites were also commonly observed on the surface of $G$. hottentottus on which they are phoretic.

\section{Vector identification by light microscopy}

Based on the results of the plating studies, we focussed on the visual detection of Gondwanamyces proteae ascospores on Trichouropoda sp. only. Even though the incidence of spore-carrying individuals of this species was fairly high, it was possible only to detect ascospores of G. proteae on two wild-caught individuals using light microscopy. In both cases the spores were situated within depressions at the base of the second pair of legs of the mites (Fig 1). Spores of various other unidentified fungal species were also observed in these depressions.

\section{Dispersal of Gondwanamyces proteae}

Fourteen individuals of Genuchus hottentottus were collected from the emergence cages. Forty-four Trichouropoda sp. mites 


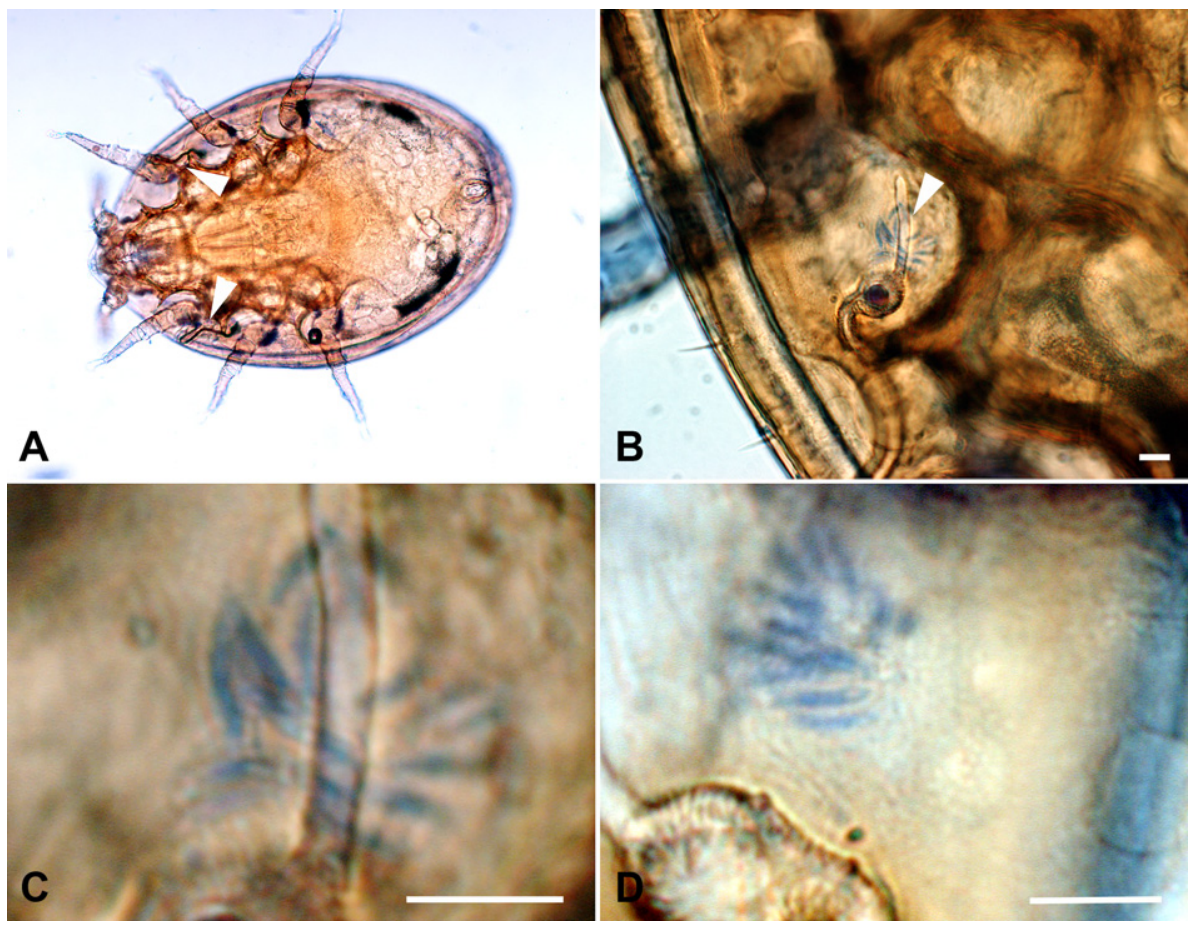

Fig 1 - Ascospores of Gondwanamyces proteae on Trichouropoda sp. mites collected from P. repens infructescences. (A) Ventral side of mite showing location where G. proteae spores are generally carried (arrows). (B) Gondwanamyces proteae ascospores (arrow) associated with depression at base of legs. (C) Same, enlarged. (D) Ascospores of G. proteae on a different mite individual. Scale bars: $10 \mu \mathrm{m}$.

were collected from the beetles at an average of $3.14( \pm 2.41)$ mites per individual beetle. Mites were usually found at the base of the first pair of legs or in the junction between the head and thorax of the beetles. Custingophora colonies were initiated from nine of the mites collected from flying $G$. hottentottus $(20.45 \%$ of total mites).

Inoculation of MEA with Gondwanamyces proteae by mites

Twenty-one of the 131 Trichouropoda sp. mites (16. $03 \%$ ) collected from the artificial 'infructescences' and plated revealed the presence of Custingophora. Most plates that were inoculated with live individual mites were overgrown with fast growing mould genera (e.g. Penicillium and Cladosporium spp.) within a week. However, colonies of the slow-growing Custingophora proteae were found on five of the 250 plates (0.02\%) occupied by individual mites. This represents a transfer rate of $8.8 \%$, if we assume that ca. $16 \%$ of the individual mites initially transferred to the plates carried G. proteae ascospores.

\section{Discussion}

Results of this study provide the first evidence that Protea-associated Gondwanamyces spp. are vectored by arthropods, a prediction made when the first species in this genus (as Ceratocystiopsis proteae) was described (Wingfield et al. 1988). The results also suggest that the most common vector for Gondwanamyces proteae on Protea repens is a mite species in the genus
Trichouropoda. This contrasts with results from recent studies that suggested a close association between Gondwanamyces species and Scolytodes bark beetles in Costa Rica (Hulcr et al. 2007; Kolarik \& Hulcr 2009). The discovery of mites as the vectors of Gondwanamyces from Protea hosts stresses the importance of studying the ecology and evolution of this system in greater depth. For example, it is possible that mites may influence the vectoring of fungal spores in Scolytodes-associated Gondwanamyces. This discovery also indicates that mites should receive more attention as possible significant vectors of fungal species in other systems that involve fungi, which occupy similar niches to Gondwanamyces (e.g. Ceratocystis spp.), and where mite associations have not yet been investigated. For example, mites may also play a significant role in the Nitidulid beetle - Ceratocystis systems investigated by e.g. Juzwik et al. (1998), Cease \& Juzwic (2001) and Heath et al. (2009).

This study has exposed a remarkable overlap in the arthropods responsible for vectoring Ophiostoma and Gondwanamyces on Protea hosts. Five mite species were identified as vectors of Gondwanamyces spores. Three of these (Proctolaelaps vandenbergi, the Tarsonemus sp. and the Trichouropoda sp.) have also been shown to be vectors of Ophiostoma from Protea (Roets et al. 2007). In that study, $14 \%$ of the Trichouropoda individuals, $2 \%$ of the Tarsonemus individuals, and $0.8 \%$ of the P. vandenbergi individuals were found to carry spores of Ophiostoma on numerous Protea spp. In P. repens specifically, only the Trichouropoda sp. was found to carry spores of Ophiostoma, where $18 \%$ of the tested individuals carried Ophiostoma spores. Here we show that this mite species is likely to also be the main vector 
for G. proteae. Interestingly, fairly similar proportions of these mites carry spores of Ophiostoma and Gondwanamyces (18\% and $13 \%$ respectively).

In addition to mites, a few individuals of a diverse range of insects (Euderes lineicolis, Genuchus hottentottus, Oxycarenus maculates and a psocopteran species) were found to carry reproductive propagules of Gondwanamyces. Similarly, Roets et al. (2007) isolated Ophiostoma from $P$. repens-associated $G$. hottentottus, 0 . maculates and a different psocopteran species. As noted by Roets et al. (2007), when compared to the high numbers of infructescences colonised by Gondwanamyces and Ophiostoma in the field, these insects are found in Protea infructescences at low frequencies (Coetzee \& Giliomee 1987a; 1987b; Roets et al. 2006b). However, contrary to what has previously been suggested, we believe that the presence of both fungal genera on these insects indicates that they may play a significant role in the dissemination of ophiostomatoid spores in this niche.

Long-range dispersal of $P$. vandenbergi, the Tarsonemus sp. and the Trichouropoda sp. has been shown to involve phoresy via various large beetles (Coleoptera: Scarabaeidae) that frequent Protea infructescences (Roets et al. 2009a). The Trichouropoda sp. mite was, however, only found phoretic on $G$. hottentottus. Combined results of the present study and that of Roets et al. (2009a) suggest that the P. repens-associated Gondwanamyces and Ophiostoma spp. are likely to be primarily dispersed by the Trichouropoda sp., while the G. hottentottus beetles play a secondary role. Protea-associated Ophiostoma and Gondwanamyces thus not only share similar morphologies and the same microhabitat (infructescences), but also have very similar ecologies in terms of their primary and secondary vectors. In addition, these genera have similar seasonal sporulation times, mainly in autumn and winter (Roets et al. 2005). The precise mechanisms that enable them to co-inhabit and thrive, usually even within a single infructescence, are still unknown, but merit further study.

Arthropod associations are common among fungi that are phylogenetically allied to Gondwanamyces. Ceratocystis spp., for example, are vectored by arthropods (Juzwik et al. 1998; Cease \& Juzwic 2001; Heath et al. 2009) with which they usually have fairly loose relationships (Moller \& DeVay 1968; Hinds 1972; Kile 1993). Seemingly more specialised species are found associated with bark beetles in their galleries (Redfern et al. 1987; Wingfield et al. 1997; Yamaoka et al. 1997). Custingophora spp. have been collected from various organic substrates, including the galleries of bark beetles (Kolarik \& Hulcr 2009), suggesting that they may be associated with various arthropods. It would therefore be very interesting to consider whether arthropodassociated fungi in the Microascales generally evolved from loose and casual associations with various arthropods to the more specialised systems involving bark and ambrosia beetles. A possible role of mites in the transmission of spores of Scolytodisassociated Gondwanamyces should, therefore, also be considered.

The importance of mites as vectors of ophiostomatoid fungi, in general, should not be underestimated. Over 90 species of mites are, for instance, associated with the southern pine beetle Dendroctonus frontalis, 14 of which are phoretic on the beetle (Moser \& Roton 1971). Many of these phoretic mites are fungivorous, and may thus also carry fungal propagules (Moser \& Roton 1971). Amongst the contingent of phoretic mites on D. frontalis, species of the genus Tarsonemus (Tarsonemus ips,
Tarsonemus krantzii, and Tarsonemus fusarii), Trichouropoda and Proctolaelaps are of special interest, as these same genera are implicated in the Protea system. They are not injurious to the beetle while in transit (Moser \& Roton 1971), but may impact the beetles indirectly by transporting additional fungal spores (Lombardero et al. 2000; Lombardero et al. 2003). Similar to the Tarsonemus sp. found on Protea, the Tarsonemus mites from $D$. frontalis possess specialised spore-carrying structures (sporothecae) that have been shown to frequently contain spores of the ophiostomatoid fungi (e.g. Ophiostoma minus) (Bridges \& Moser 1983; Moser 1985; Moser et al. 1995). These mites also have a mutualistic association with their phoretic fungi (Lombardero et al. 2000). Mites influence the population dynamics of $D$. frontalis by vectoring 0 . minus, a fungus that limits the success of the beetle mycangial fungi, and consequently lower the success of the beetles (Lombardero et al. 2000; Klepzig et al. 2001a, 2001b; Lombardero et al. 2003). Thus, these associations are very complex and include a communalism (mites and beetles), two mutualisms (mites-fungi and mycangial fungi-beetles) and competition (mite fungi us. beetle mycangial fungi) (Lombardero et al. 2003). The influence of ophiostomatoid fungi on the success of $G$. hottentottus on Protea is unknown, but may prove to be an interesting field for future study.

The infructescences of Protea represent a unusual habitat for ophiostomatoid fungi. In recent years, a suite of studies has added considerably to our understanding of this group of ecologically important fungi. However, much remains to be resolved regarding the ability of Gondwanamyces and Ophiostoma spp. to occupy seemingly similar ecological niches, simultaneously. It is plausible that other Protea-infructescence colonising organisms play a role in niche separation of these genera. In order to clarify this question, studies on the competitive abilities of these fungi in association with other organisms are needed.

\section{Acknowledgements}

We thank E. Ueckermann for the identification of the various mite species collected in this study; National Research Foundation and the NRF/DST Centre of Excellence in Tree Health Biotechnology (CTHB) for financial support; and the Western Cape Nature Conservation Board for permission to work on conserved land. Two anonymous reviewers are thanked for their valuable comments that led to the enhancement of the quality of this manuscript.

\section{R E F E R E N C E S}

Beaver RA, 1989. Insect-fungus relationships in the bark and ambrosia beetles. In: Wilding N, Collins NM, Hammond PM, Webber JF (eds), Insect-fungus Interactions. Academic Press, London, United Kingdom, pp. 121-143.

Bridges JR, Moser JC, 1983. Role of two phoretic mites in transmission of bluestain fungus, Ceratocystis minor. Ecological Entomology 8: 9-12.

Cease KR, Juzwic J, 2001. Predominant nitidulid species (Coleoptera: Nitidulidae) associated with spring oak wilt mats in Minnesota. Canadian Journal of Forest Research 31: 635-643. 
Cassar S, Blackwell M, 1996. Convergent origins of ambrosia fungi. Mycologia 88: 596-601.

Christiansen E, Waring RH, Berryman AA, 1987. Resistance of conifers to bark beetle attack: searching for general relationships. Forest Ecology and Management 22: 89-106.

Coetzee JH, Giliomee JH, 1987a. Borers and other inhabitants of the inflorescences and infructescences of Protea repens in the Western Cape. Phytophylactica 19: 1-6.

Coetzee JH, Giliomee JH, 1987b. Seed predation and survival in the infructescences of Protea repens (Proteaceae). South African Journal of Botany 53: 61-64.

de Meyer EM, de Beer ZW, Summerbell RC, Moharram AM, de Hoog GS, Vismer HF, Wingfield MJ, 2008. Taxonomy and phylogeny of new wood- and soil-inhabiting Sporothrix species in the Ophiostoma stenoceras-Sporothrix schenckii complex. Mycologia 100: 647-661.

Francke-Grosmann H, 1967. Ectosymbiosis in wood-inhabiting insects. In: Henry SM (ed.), Symbiosis. Academic Press, New York, U.S.A., pp. 171-180.

Harrington TC, Wingfield MJ, 1998. The Ceratocystis species on conifers. Canadian Journal of Botany 76: 1446-1457.

Hausner G, Reid J, Klassen GR, 1992. Do galeate-ascospore members of the Cephaloascaceae, Endomycetaceae and Ophiostomataceae share a common phylogeny? Mycologia 84: 870-881.

Hausner G, Reid J, Klassen GR, 1993a. On the phylogeny of Ophiostoma, Ceratocystis s. s., and Microascus, and relationships within Ophiostoma based on partial ribosomal DNA sequences. Canadian Journal of Botany 71: 1249-1265.

Hausner G, Reid J, Klassen GR, 1993b. On the subdivision of Ceratocystis s. l., based on partial ribosomal DNA sequences. Canadian Journal of Botany 71: 52-63.

Heath RN, Wingfield MJ, Van Wyk M, Roux J, 2009. Insect associates of Ceratocystis albifundus and patterns of association in a native Savannah ecosystem in South Africa. Environmental Entomology 38: 356-364.

Hinds TE, 1972. Insect transmission of Ceratocystis species associated with aspen cankers. Phytopathology 62: 221-225.

Hulcr J, Kolarik M, Kirkendall LR, 2007. A new record of fungus-beetle symbiosis in Scolytodes bark beetles (Scolytinae, Curculionidae, Coleoptera). Symbiosis 43: 151-159.

Iton EF, 1966. Ceratocystis Wilt. Imperial College of Tropical Agriculture (University of West Indies). Annual Report on Cacao Research for 1965, pp. 48-49.

Jacobs K, Wingfield MJ, 2001. Leptographium species: tree pathogens, insect associates, and agents of blue-stain. APS press, St Paul, Minnesota, U.S.A.

Juzwik J, Cease KR, Meyer JM, 1998. Acquisition of Ophiostoma quercus and Ceratocystis fagacearum by Nitidulids from O. quercus-Colonized Oak Wilt Mats. Plant Disease 82: 239-243.

Kamgan NG, Jacobs K, de Beer ZW, Wingfield MJ, Roux J, 2008. Ceratocystis and Ophiostoma species including three new taxa, associated with wounds on native South African trees. Fungal Diversity 29: 37-59.

Kile GA, 1993. Plant diseases caused by species of Ceratocystis sensu stricto and chalara. In: Wingfield MJ, Seifert KA, Webber JF (eds), Ceratocystis and Ophiostoma: taxonomy, ecology and pathogenicity. American Phytopathological Society Press, St. Paul, Minnesota, pp. 173-183.

Kirisits T, 2004. Fungal associates of European bark beetles with special emphasis on the ophiostomatoid fungi. In: Lieutier F, Day KR, Battisti A, Grégoire JC, Evans H (eds), Bark and Wood Boring Insects in Living Trees in Europe, a Synthesis. Kluwer Academic Press, Dordrecht, The Netherlands, pp. 1-55.

Klepzig KD, Moser JC, Lombardero MJ, Ayres MP, Hofstetter RW, Walkinshaw CJ, 2001a. Mutualism and antagonism: Ecological interactions among bark beetles, mites and fungi. In: Jeger MJ, Spence NJ (eds), Biotic Interactions in Plant-Pathogen Associations. CAB International, New York, U.S.A., pp. 237-267.
Klepzig KD, Moser JC, Lombardero FJ, Hofstetter RW, Ayres MP, 2001b. Symbiosis and competition: complex interactions among beetles, fungi and mites. Symbiosis 30: 83-96.

Kolarik M, Hulcr J, 2009. Mycobiota associated with the ambrosia beetle Scolytodes unipunctatus (Coleoptera: Curculionidae, Scolytinae). Mycological Research 113: 44-60.

Krokene P, Solheim H, 1998. Pathogenicity of four blue-stain fungi associated with aggressive and nonaggressive bark beetles. Phytopathology 88: 39-44.

Lombardero MJ, Ayres MP, Hofstetter MW, Moser MC, Klepzig KD, 2003. Strong indirect interactions of Tarsonemus mites (Acarina: Tarsonemidae) and Dendroctonus frontalis (Coleoptera: Scolytidae). Oicos 102: 243-252.

Lombardero MJ, Klepzig KD, Moser JC, Ayres MP, 2000. Biology, demography, and community interactions of Tarsonemus (Acarina: Tarsonemidae) mites phoretic on Dendroctonus frontalis (Coleoptera: Scolytidae). Agricultural and Forest Entomology 2: 193-202.

Malloch D, Blackwell M, 1993. Dispersal biology of the ophiostomatoid fungi. In: Wingfield MJ, Seifert KA, Webber JF (eds), Ceratocystis and Ophiostoma: taxonomy, ecology and pathogenicity. APS Press, St. Paul, U.S.A., pp. 195-206.

Marais GJ, Wingfield MJ, Viljoen CD, Wingfield BD, 1998. A new ophiostomatoid genus from Protea infructescences. Mycologia 90: 136-141.

Marais GJ, Wingfield MJ, 1994. Fungi associated with infructescences of Protea species in South Africa, including a new species of Ophiostoma. Mycological Research 98: 369-374.

Marais GJ, Wingfield MJ, 1997. Ophiostoma protearum sp. nov. associated with Protea caffra infructescences. Canadian Journal of Botany 75: 362-367.

Marais GJ, Wingfield MJ, 2001. Ophiostoma africanum sp. nov., and a key to ophiostomatoid species from Protea infructescences. Mycological Research 105: 240-246.

Moller W, DeVay J, 1968. Insect transmission of Ceratocystis fimbriata in deciduous fruit orchards. Phytopathology 58: 1499-1508.

Moser JC, 1985. Use of sporothecae by phoretic Tarsonemus mites to transport ascospores of coniferous bluestain fungi. Transactions of the British Mycological Society 84: 750-753.

Moser JC, Perry TJ, Bridges JR, Yin HF, 1995. Ascospore dispersal of Ceratocystiopsis ranaculosus, a mycangial fungus of the southern pine beetle. Mycologia 87: 84-86.

Moser JC, Roton LM, 1971. Mites associated with southern pine bark beetles in Allen Parish, Lousiana. The Canadian Entomologist 103: 1775-1798.

Münch E, 1907. Die Blaufäule des Nadelholzes I-II. Naturwissenschaftliche Zeitschrifr für Land- und Forstwitschaft 5: 531-573.

Münch E, 1908. Die Blaufäule des Nadelholzes. III-IV. Naturwissenschaftliche Zeitschrifr für Land- und Forstwitschaft 6: 32-47 297-323.

Paine TD, Raffa KF, Harrington TC, 1997. Interactions among Scolytid bark beetles, their associated fungi, and live host conifers. Annual Review of Entomology 42: 179-206.

Pinnoi A, McKenzie EHC, Jones EBG, Hyde KD, 2003. Palm fungi from Thailand: Custingophora undulatistipes sp. nov. and Vanakripa minutiellipsoidea sp. nov. Nova Hedwigia 77: 213-219.

Redfern DB, Stoakley JT, Steele H, 1987. Dieback and death of larch caused by Ceratocystis laricicola sp. nov. following attack by Ips cembrae. Plant Pathology 36: 467-480.

Roets F, Crous PW, Dreyer LL, 2005. Seasonal trends in colonization of Protea infructescences by Gondwanamyces and Ophiostoma spp. South African Journal of Botany 71: 307-311.

Roets F, de Beer ZW, Dreyer LL, Zipfel R, Crous PW, Wingfield MJ, 2006a. Multigene phylogeny for Ophiostoma spp. reveals two new species from Protea infructescences. Studies in Mycology 55: 199-212. 
Roets F, Dreyer LL, Geertsema HG, Crous PW, 2006b. Arthropod communities in Proteaceae infructescences: seasonal variation and the influence of infructescence phenology. African Entomology 14: 257-265.

Roets F, Wingfield MJ, Dreyer LL, Crous PW, Bellstedt DU, 2006c. A PCR-based method to detect Ophiostoma and Gondwanamyces from the surface of insects colonising Protea flowers. Botany 84: 989-994.

Roets F, Crous PW, Wingfield MJ, Dreyer LL, 2007. Discovery of fungus-mite-mutualism within a unique niche of the Cape Floral Kingdom. Environmental Entomology 36: 1226-1237.

Roets F, de Beer ZW, Wingfield MJ, Crous PW, Dreyer LL, 2008. Ophiostoma gemellus and Sporothrix variecibatus from mites infesting Protea infructescences in South Africa. Mycologia 100: 496-510.

Roets F, Dreyer LL, Crous PW, Wingfield MJ, 2009a. Mite-mediated hyperphoretic dispersal of Ophiostoma spp. from the infructescences of South African Protea spp. Environmental Entomology 38: $143-152$.

Roets F, Wingfield MJ, Crous PW, Dreyer LL, 2009b. Fungal Radiation in the Cape Floristic Region: an analysis based on Gondwanamyces and Ophiostoma. Molecular Phylogenetics and Evolution 51: 111-119.

Roets F, Wingfield MJ, Wingfield BD, Dreyer LL, 2010. Two new species of Ophiostoma from Protea caffra in Zambia. Persoonia 24: 18-28.

Seifert KA, Wingfield MJ, Kendrick WB, 1993. A nomenclator for described species of Ceratocystis, Ophiostoma, Ceratocystiopsis, Ceratostomella and Sphaeronaemella. In: Wingfield MJ, Seifert KA, Webber JF (eds), Ceratocystis and Ophiostoma: taxonomy, ecology and pathogenicity. APS Press, Minnesota, U.S.A., pp. 269-288.

Sinclair WA, Lyon H, Johnson WT, 1987. Diseases of Trees and Shrubs. Cornell University Press, Ithaca, New York, U.S.A.
Spatafora JW, Blackwell M, 1994. The polyphyletic origins of ophiostomatoid fungi. Mycological Research 98: 1-9.

Stolk H, Hennebert GL, 1968. Thysamophora and Custingophora. Persoonia 5: 195-199.

Upadhyay HP, 1981. A Monograph of Ceratocystis and Ceratocystiopsis. University of Georgia Press, Athens, U.S.A.

Vilgalys R, Hester M, 1990. Rapid genetic identification and mapping of enzymatically amplified ribosomal DNA from several Cryptococcus species. Journal of Bacteriology 172: 4238-4246.

Viljoen CD, Wingfield BD, Wingfield MJ, 1999. Relatedness of Custingophora olivaceae to Gondwanamyces spp. from Protea spp. Mycological Research 103: 497-500.

Wingfield MJ, Harrington TC, Solheim H, 1997. Two species in the Ceratocystis coerulescens complex from conifers in western North America. Botany 75: 827-834.

Wingfield MJ, Seifert KA, Weber JF, 1993. Ceratocystis and Ophiostoma: taxonomy, ecology and pathogenicity. APS Press, St. Paul, U.S.A.

Wingfield MJ, Van Wyk PS, 1993. A new species of Ophiostoma from Protea infructescences in South Africa. Mycological Research 97: 709-716.

Wingfield MJ, Van Wyk PS, Marasas WFC, 1988. Ceratacystiopsis proteae sp. nov., with a new anamorph genus. Mycologia 80: 23-30.

Whitney HS, 1982. Relationships between bark beetles and symbiotic organisms. In: Mitton JB, Sturgeon KB (eds), Bark Beetles in North American Conifers. University of Texas Press, Austin, U.S.A..

Yamaoka Y, Wingfield MJ, Takahashi I, Solheim H, 1997. Ophiostomatoid fungi associated with the spruce bark beetle Ips typographus f. japonicus in Japan. Mycological Research 101: 1215-1227. 